\title{
MOLECULAR IDENTIFICATION OF CUCURBIT FLY Dacus ciliatus (DIPTERA: TEPHRITIDAE) INFEST CUCURBITACEAE FAMILY BASED ON MITOCHONDRIAL GENE IN KURDISTAN REGION- IRAQ.
}

\author{
Gehan Haji Maronsy ${ }^{*}$ and Shamal Abdullah Al-Muffti ${ }^{* * *}$ \\ * Dept. of Plant Protection, College of Agricultural Engineering Sciences, University of Duhok, \\ Kurdistan Region-Iraq \\ *** Dept. of Biology, College of Science, University of Duhok, Kurdistan Region-Iraq
}

(Received: October 31, 2019; Accepted for Publication: December 24, 2019)

\begin{abstract}
- Fruit fly hosts survey was carried out in many villages at three provinces (Duhok, Erbil and Sulaimaniyah /Kurdistan region, Iraq) during period 15/9-1/12/2017 and 15/5-30/9/2018. Ethiopian fruit fly Dacus ciliates (Loew) which belongs to the genus Dacus, family Tephritidae, order Diptera were found infesting most vegetables like cucubitaceae and some of fruit trees like fig. For molecular identification, polymerase chain reaction (PCR) amplification technique was used to amplify a single or a few copies of a pieces of DNA to millions of copies of a particular DNA sequence. For rearing this pest, damaged fruits were collected and kept in a round cages galvanized by sieves cloth $(35 \mathrm{~cm}$ diameter, $40 \mathrm{~cm}$ hight), containing a layer of $\mathbf{3} \mathrm{cm}$ soil to facilitate pupation
\end{abstract}

KEYWORDS: Fruit flies, Tephritidea, Dacini, Molecular, Mitochonderial DNA.

https://doi.org/10.26682/ajuod.2019.22.2.22

\section{INTRODUCTION}

$\mathbf{T}$ ephritid fruit flies are considered an insect group of major economic significance in agriculture. It's attack different types of commercial and wild fruits and vegetables, causing considerable damage to agricultural crops (De Meyer et al.2012). There are about 450 genera and about 4,300 described species within Tephritidae family in the worldwide, making it one of the largest families within Diptera (Norrbom et al. 1998). The fruit fly species that cause the damage are not well known. Sub-Saharan Africa is the aboriginal home to 915 fruit fly species from 148 genera, of which 299 species develop in either wild or cultivated fruit. Both of the lesser pumpkin fly, Dacus ciliatus (Loew) and the greater pumpkin fly, Dacus frontalis (Becker) which belong order Diptera family Tephritidae (Typetidae or Trupaneidae) are a group of about 4000 known species and nearly about $80 \%$ of their larvae develop in the seeds (flowers or fruits) of higher plants, and therefore known as fruit flies (White, 2000). Both flies are serious pests that cause high loss in yield and cause damage sometimes reached 100\%. According EPPO (2009) both species could be arranged as highly serious agricultural pests.

The genus Dacus causes severe damage to fruits and vegetables in Asia. The cucumber fly, D. ciliatus was recorded as a serious pest on cucurbitaceae since 1947 by Azab and Kira (1954), continued nearly untill 1980 and disappeared then appeared again after 25 years in Egypt (Fetoh, 2003). Dacus ciliatus Loew., is a major pest of the most of eastern, southern, and central Africa, Arabian Peninsula, Pakistan and India. (Azab, et al., 1970; Nagappan et al., 1971; White and Elson-Harris, 1994). It is also known as Ethiopian fruit fly. D. ciliatus is a pest of the most of eastern, southern, and central Africa, Arabian Peninsula, Pakistan and India. Its color is orange, with facial spots. There are two black spots in abdomen particularly in females (White and Elson-Harris, 1994). The fruits of cucumbers are exposed to being infected with six types of flies in autumnal cultivation in central Iraq, and these species are arranged according to their economic importance as Dacus ciliatus (Loew), Dacus frontalis(Becker), Atherigona orintalis (Schin.), Atherigona varia(Meigen), Myiopardalis pardalina (Bigot) and Ceratitis capitata (Wiedeman) Al-Jorany et. 
al. (2015). In Iran, (Fars, Khorasan Razavi, Tehran, Khuzestan and Hormozgan) provinces. this pest is a major pest of cucumber, watermelon and cantaloupe. Also milkweed and colocynth are other hosts of this pest in Iran (Arghand, 1983 and Cheraghian, 2012). Many species of these Tephritid fruit flies are morphologically similar but differ in their behavior such as reproductive potentials, competitive abilities and dispersive power (Duyck et. al. 2004). Generally, accurate identification of insect species is essential, especially in the sibling species, in order to give right information for ecology, biology and control methods, the molecular biology methods helps to classify and control pests in clear, easy and quick manner. PCR is now a common and often indispensable technique. There are three major steps involved in the PCR technique: denaturation, annealing, and extension.

The main objective of this work is to differentiate the Ethiopian fruit fly, D. ciliatus from other species of the same genus by molecular and morphological characters.

\section{MATERIALS AND METHODS}

First: Survey

- Fields in three governorates (Duhok, Erbil, and Sulaimaniyah) / Kurdistan region - Iraq were selected. The fields and their locations Y(lat) and $\mathrm{X}$ (long) are shown in Table (1) \& Fig. (1).

Table (1): Cucurbit fly's specimens collected from locations in Kurdistan region Iraq during

\begin{tabular}{|c|c|c|c|c|}
\hline No. & Governorate & Location & $\begin{array}{c}* \\
\mathrm{X}(\text { long }) \\
\end{array}$ & $\begin{array}{c}* * \\
Y^{*}(\text { lat }) \\
\end{array}$ \\
\hline \multirow{3}{*}{1} & \multirow{3}{*}{ Duhok } & Summel & 36.51 & 42.59 \\
\hline & & Qadish & 37.05 & 43.21 \\
\hline & & Bamarze & 36.36 & 43.34 \\
\hline \multirow{3}{*}{2} & \multirow{3}{*}{ Erbil } & Selke & 36.41 & 44.58 \\
\hline & & Khalifan & 37.15 & 42.15 \\
\hline & & Gardasher & 36.17 & 43.50 \\
\hline \multirow{3}{*}{3} & \multirow{3}{*}{ Sulaymanyiah } & Khalakan & 36.01 & 44.50 \\
\hline & & Hassan tappa & 36.52 & 43.48 \\
\hline & & Basharat upper & 35.54 & 44.58 \\
\hline
\end{tabular}

\footnotetext{
$* \overline{\mathrm{X}}$ (long. $)=$ Longitude $\quad * * \mathrm{Y}($ lat. $)=$ Latitude
} 


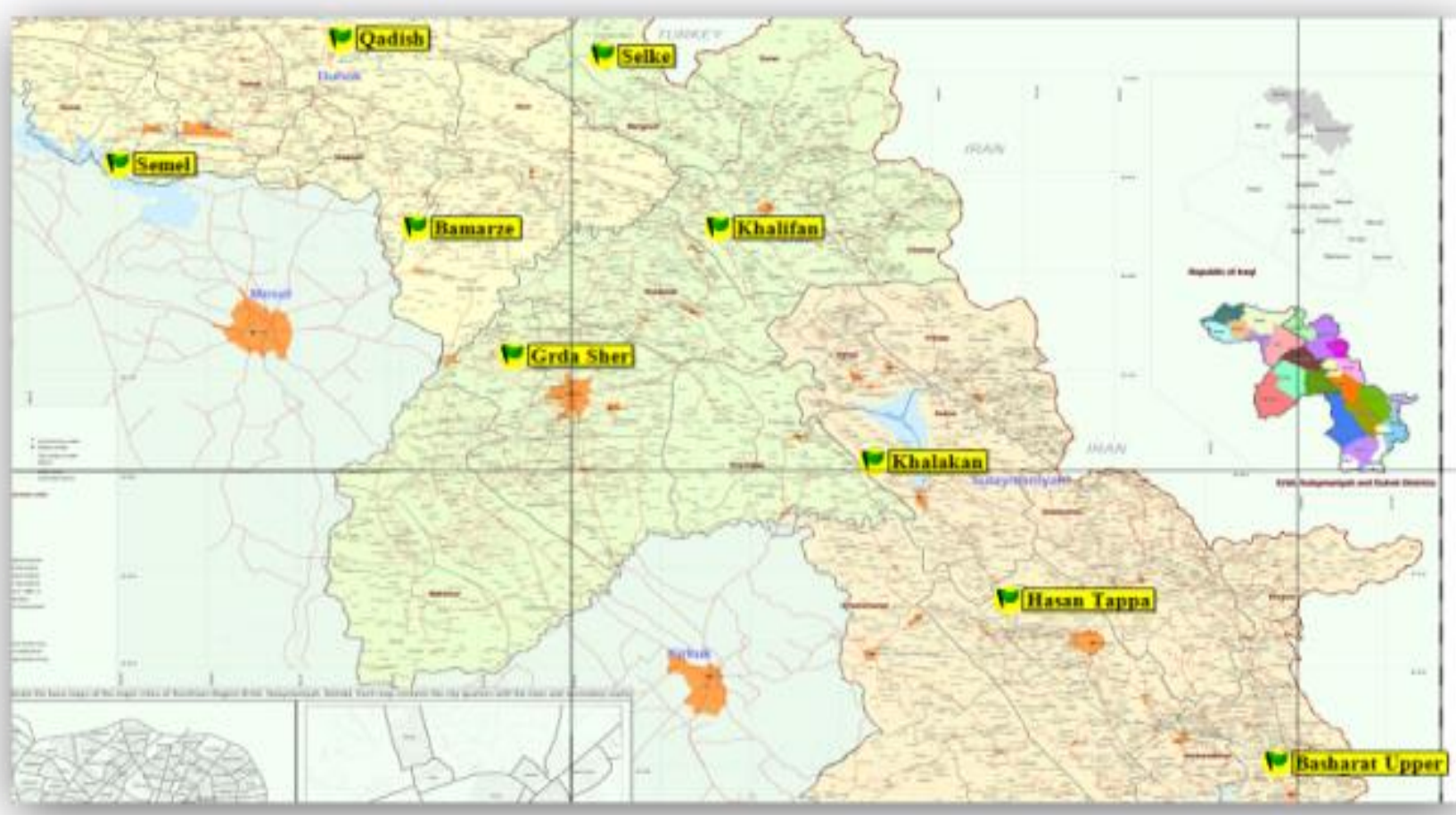

Fig. (1): Shows the survey areas of Dacus ciliatus : The sampling location

\section{Second:Samples collection}

Samples of Dacus ciliatus were collected from cucurbit fields (squash and cucumber fields) weekly during period of pest activity (late of May until the late of October) in the 2017 and 2018 from many villages at Duhok, Erbil and Sulaymaniyah in Kurdistan region, Iraq. The infested small cucumbers and squash with larvae were collected and transferred to laboratory.

Third: Insect sample's preparation (insect stock)

Damaged fruits, that were collected from 9 localities of the three Governorates during the late of May until the late of October, were kept in a round cages galvanized by sieves cloth (35 $\mathrm{cm}$ diameter, $40 \mathrm{~cm}$ height), containing a layer of $2 \mathrm{~cm}$ soil to facilitate pupation. A sugar solution (10\%) was used for feeding the adults in the cages. Insect rearing and all bioassay tests were performed at $26 \pm 1{ }^{\circ} \mathrm{C}$ and $65 \pm 5 \%$ relative humidity under a $12: 12$ (L: D) photoperiod in the growth chamber (Vayssie'res et. al. 2008) and (Hussein et.al. 2006). The adults kept in plastic containers filled with $96 \%$ alcohol for maintaining the insect's sample for molecular study. (Jalali et. al. 2015).
Hundred specimens had been selected for the extraction of DNA. Fifty specimens were sent to the sequences (Intergene genetic center/ Ankara / Turkey). The steps of this work were summarized as following:

1. Extract the Mitochondrial DNA (mtDNA) of the Ducus ciliatus.

2. Use the specific species primer for amplifying the mitochondrial DNA.

3. A mitochondrial DNA was amplifying by PCR (Polymerase Chain Reaction) technique.

4. Purification of the mtDNA product had done for the step three.

5. Purified mtDNA product had sent to the sequencing.

6. Compare the results of sequencing with the samples of the neighbor regions of Kurdistan.

Fifth: Chemicals and primers that used in this research

A/ Chemicals need in molecular technique were:
1) PCR Buffer
2) $\mathrm{MgCl} 2$
3) dNTP
4) TAQ
5) $\mathrm{H} 2 \mathrm{O}$ (sterile water) 


\section{B/ The Primers:}

Mitochondrial Cytochrome Oxidase Subunit I gene (COI): (Folmer et.al. 1994)

LCO1490F 5'-

GGTCAACAAATCATAAAGATATTGG-3'

HCO2198R 5'-

TAAACTTCAGGGTGACCAAAAAATA-3'

C/ DNA Extraction Kit

Qiagen DNAeasy Tissue Extraction Kit

* Extraction of mtDNA.

The following chemicals were used for mtDNA extraction :

1- Lysis Buffer
2- Phenol

3- Chloroform

4- Ammonium acetate

5- Absolute ethanol

6- TE Buffer

\section{*Polymerase Chain Reaction (PCR) Amplification}

The mitochondrial DNA polymerase chain reaction (mtDNA-PCR) method was used to amplifying the mtDNA of selected samples. All the chemicals that are used in this step shown in Table2

(Table2): The Chemicals used for one sample

\begin{tabular}{cc}
\hline Volume & Reagent name \\
\hline $5.0 \mu \mathrm{L}$ & PCR Buffer \\
\hline $8.0 \mu \mathrm{L}$ & MgCl2 \\
\hline $1.25 \mu \mathrm{L}$ & dNTP \\
\hline $1.25 \mu \mathrm{L}$ & Primer F \\
\hline $1.25 \mu \mathrm{L}$ & Primer R \\
\hline $0.25 \mu \mathrm{L}$ & TAQ \\
\hline $7.5 \mu \mathrm{L}$ & $\mathrm{H} 2 \mathrm{O}$ \\
\hline $24.5 \mu \mathrm{L}$ & Total master mix \\
\hline $0.5 \mu \mathrm{L}$ & Template DNA
\end{tabular}

Table (3): Kit components

\begin{tabular}{ccc}
\hline Cat.No. & $\begin{array}{c}\text { K-3000 } \\
\text { (50 prep.) }\end{array}$ & $\begin{array}{c}\text { K-3001 } \\
\text { (200 prep.) }\end{array}$ \\
\hline Spin column & 50 ea & 50 ea $x$ 4 \\
\hline Collection tube & 100 ea & 100 ea $x 4$ \\
\hline Buffer TL & $20 \mathrm{ml}$ & $20 \mathrm{ml} \times 4$ \\
\hline Buffer GB & $12 \mathrm{ml}$ & $12 \mathrm{ml} \times 4$ \\
\hline Buffer GW1 & $20 \mathrm{ml}$ & $20 \mathrm{ml} \times 4$ \\
\hline Buffer GW2 & $10 \mathrm{ml}$ & $10 \mathrm{ml} \times 4$ \\
\hline Buffer GE & $10 \mathrm{ml}$ & $10 \mathrm{ml} \times 4$ \\
\hline $\begin{array}{c}\text { Proteinase K } \\
\text { Sol.(20mg/ml) (should } \\
\left.\text { be stored at }-20{ }^{\circ} \mathrm{C}\right)\end{array}$ & $1.2 \mathrm{ml}$ & $1.2 \mathrm{ml} \times 4$ \\
\hline
\end{tabular}

D/ PCR Program for the COI gene:

1- Hot start temperature $95^{\circ} \mathrm{c}$ (for 5 minute)

2- Denaturation temperature $95^{\circ} \mathrm{c}$ (for 1 minute)

3 - Annealing temperature $55^{\circ} \mathrm{c}$ (for 1 minute)

4- Extension temperature $75^{\circ} \mathrm{c}$ (for 1.45 minute)

5 - The above steps are repeated for 35 cycles

6 - The final extension temperature $72^{\circ} \mathrm{c}$ (for 5 minute)

\section{E: Sequencing step:}

The amplified products which had been obtained from PCR analysis were sent to commercial sequencing company (Intergene genetic center/ Ankara). Each sample was bi directionally sequenced and checked for quality 1and frame shifts by using NCBI BLAST. All sequences were uploaded to GenBank.

\section{RESULTS AND DISCUSSION *Morphological identification of Dacus ciliatus: \\ The fruit fly specimens (Fig. 2) were} identified according to key of the species Dacus ciliates. (Diptera: Tephritidae: Dacinae) by Luc Leblanc, et.al. (2013). Adults of Dacus species were identified according to morphological features, accepted with Menon et.al.(1968), Malan \& Giliomee (1969), and Azab et.al. (1971).

Characters of Dacus ciliatus:

Adult semi-oval peaked toward the posterior part.

2- Length 4-5 mm, width 2-2.5 mm.

3- Yellow head with brown thorax and abdomen. 
4- The legs are yellow in color.

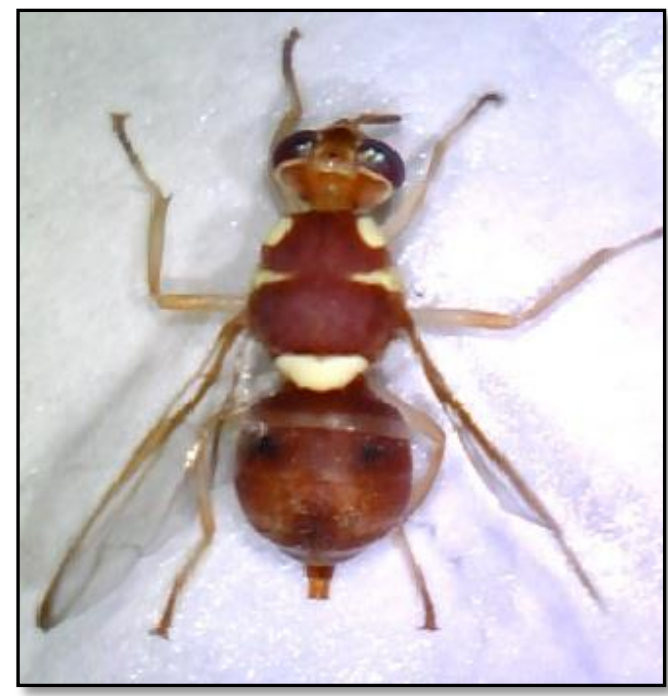

Fig. (2): Cucurbit fly adult

\section{*Molecular Identification: \\ * PCR amplification:}

The identification of the species was determined by using the mitochondrial DNA polymerase chain reaction (mtDNA-PCR) method. The arrangement of genes in mitochondrial genomes has been studied in insects. The results of PCR amplification detected one band as shown in Fig.(3) indicated that there is only one species of Dacus namely: Dacus ciliatus. The length of the polymerase chain reaction products is 708bp.while Morphological classification used in this study revealed that there are two different Dacus species.

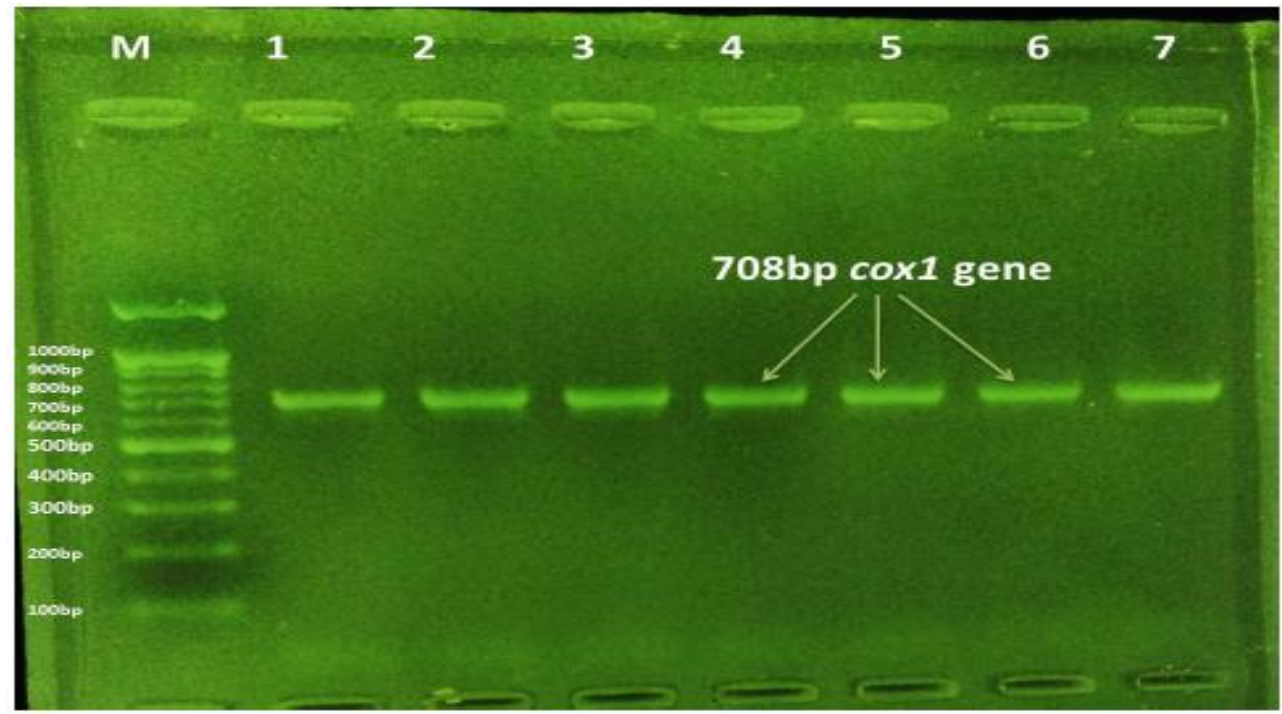

Fig. (3): Agarose gel electrophoresis of species specific PCR amplification of Dacus ciliatus genomic DNA. Electrophoresis performed on 1\% Agarose gel and run with 3 volt $/ \mathrm{cm}$. Lane 1= Marker (Molecular weight marker is a 1000bp ladder; it means that each band with the next one has 100bp difference), lane 1-7 Dacus ciliatus (each of them isolated from single adult specimen cucurbit fly), the length of the polymerase chain reaction products is $708 \mathrm{bp}$. 
Fifteen species of insects have had their mitochondrial genomes sequenced completely; the mitochondria of insects contain their own double-stranded circular genomes, which range from 14,503 bp (Beckenbach and Joy 2009) to 19,517 bp in size (Lewis et al. 1995). The DNA that was extracted from somatic tissue in mitochondria was subjected to PCR amplification of $708 \mathrm{bp}$ region near the 5' terminus of the COI gene following standard protocols.

The sequence of bases of (MK 287888) Iraq D. ciliates

1 atcataaaga tattggaaca ttatatttta ttttcggagc ctgagcaggc atagtaggaa

61 catccettag aattctagtt cgtgctgaat taggacaccc cggagcttta attggagacg

121 accaaattta taacgtaatt gtaacagctc acgcatttgt aataattttc tttatagtaa

181 tacctattat aattggaggg tttggaaatt gattagtacc attaatatta ggtgctccag

241 atatagcatt ccccogaata aataatataa gttttgatt actaccecca tctcttacet

301 tacttttagt cagcagtata gtggaaaacg gagctggaac aggttgaaca gtgtatcctc

361 ctctatcatc aatcattgct cacggaggag catctgtaga tttagctatc ttttccttac

421 atttagcagg tatttcttca attttagggg ctgtaaattt tattacaaca gttattaata

481 tacgatctac aggaattagt tttgaccgaa tacctctatt tgtttgagct gttgtattaa

541 ctgcattatt attacttctt tccettccag tactagctgg agctattact atattattaa

601 cagaccgaaa cttaaacaca tettcttcg acccegctgg aggaggagac cctattcttt

661 accaacattt atttgattt tttggtcacc ctgaag

The sequence of bases of (MK 287889) Iraq D. ciliates

1 aaatcataaa gatattggaa cattatattt tattttcgga gcctgagcag gcatagtagg

61 aacatccett agaattctag ttcgtgctga attaggacac cccggagctt taattggaga

121 cgaccaaatt tataacgtaa ttgtaacagc tcacgcattt gtaataattt tctttatagt

181 aatacctatt ataattggag ggtttggaaa ttgattagta ccattaatat taggtgctcc

241 agatatagca ttccccegaa taaataatat aagtttttga ttactacctc catctcttac

301 cttactttta gtcagcagta tagtggaaaa cggagccgga acaggttgaa cagtgtatcc
361 ccctctatca tcagtcattg ctcacggagg agcatctgta gatttagcca tcttttcctt

421 acatttagca ggtatttctt caattttagg ggctgtaaat tttattacaa cagttattaa

481 tatacgatct acaggaatta gctttgaccg aatacctctg tttgtttgag ctgttgtatt

541 aactgcatta ttattacttc tttcecttcc agtactagct ggagctatta ctatattatt

601 aacagaccga aacttaaaca catctttctt cgaccccgct ggaggaggag accctattct

661 ttaccaacat ttatttgat tttttggtca ccetgaag

The sequence of bases of (MK 287890) Iraq D. ciliates

1 ctttatgatt tgttgacaaa tcataaagat attggaacat tatattttat tttcggagcc

61 tgagcaggca tagtaggaac atccettaga attctagttc gtgctgaatt aggacacccc

121 ggagctttaa ttggagacga ccaaatttat aacgtaattg taacagctca cgcatttgta

181 ataatttct ttatagtaat acctattata attggagggt ttggaaattg attagtacca

241 ttaatattag gtgctccaga tatagcattc ccccgaataa ataatataag tttttgatta

301 ctacctccat ctcttacett acttttagtc agcagtatag tggaaaacgg agccggaaca

361 ggttgaacag tgtatccccc tctatcatca gtcattgctc acggaggagc atctgtagat

421 ttagccatct tttccttaca tttagcaggt atttcttcaa ttttaggggc tgtaaatttt

481 attacaacag ttattaatat acgatctaca ggaattagct ttgaccgaat acctctgttt

541 gtttgagctg ttgtattaac tgcattatta ttacttcttt ccettccagt actagctgga

601 gctattacta tattattaac agaccgaaac ttaaacacat ctttcttcga cccegctgga

661 ggaggagacc ctattcttta ccaacattta ttttgatttt ttggtcaccc tgaag

\section{Final Remark:}

All the specimens of Dacus species that were collected from three sites of Kurdistan region /Iraq were subjected to morphological characterization using different classification keys (David et al., 2011; Drew et al., 2002; Drew et al., 2007; Drew et al., 2013; and Leblanc et al., 2013). Results showed that there is only one species of Dacus species populated in this region called Dacus ciliates. Molecular techniques are providing the scientists with more mechanistic tools for scientists to confirm the organism, so that the molecular techniques are a 
uniform and practical method for species identification of insects. The mitochondria of insects contain their own double-stranded circular genomes (Fig 4), which range from 14,503 bp (Beckenbech and Joy 2009) to 19,517 bp in size (Lewis et al. 1995). The agarose Gel electrophoresis of the PCR products for about 100 specimens, with the species-specific primers indicated that there is only one species of Dacus (Dacus ciliates) in Kurdistan region / Iraq. The length of the polymerase chain reaction products was approximately 708 bp. DNA sequencing which is a molecular based technique was used to confirm the above results. All sequencing results of COI-mtDNA were sent to the GenBank (in USA) to be checked. The GenBank firstly submitted a code number for each sequence as: Bankit 2174377, Bankit 2174378, and Bankit 2174379 respectively, and after about one month, the GenBank sent an accession number for each sequence in the mid of December 2019 as: MK 287888, MK 287889, and MK 287890 respectively, as clarified in Table (4). The sequencing map of COI- mtDNA of Dacus sp. that collected in Kurdistan regionIraq, has been registered as a new according to IGB.

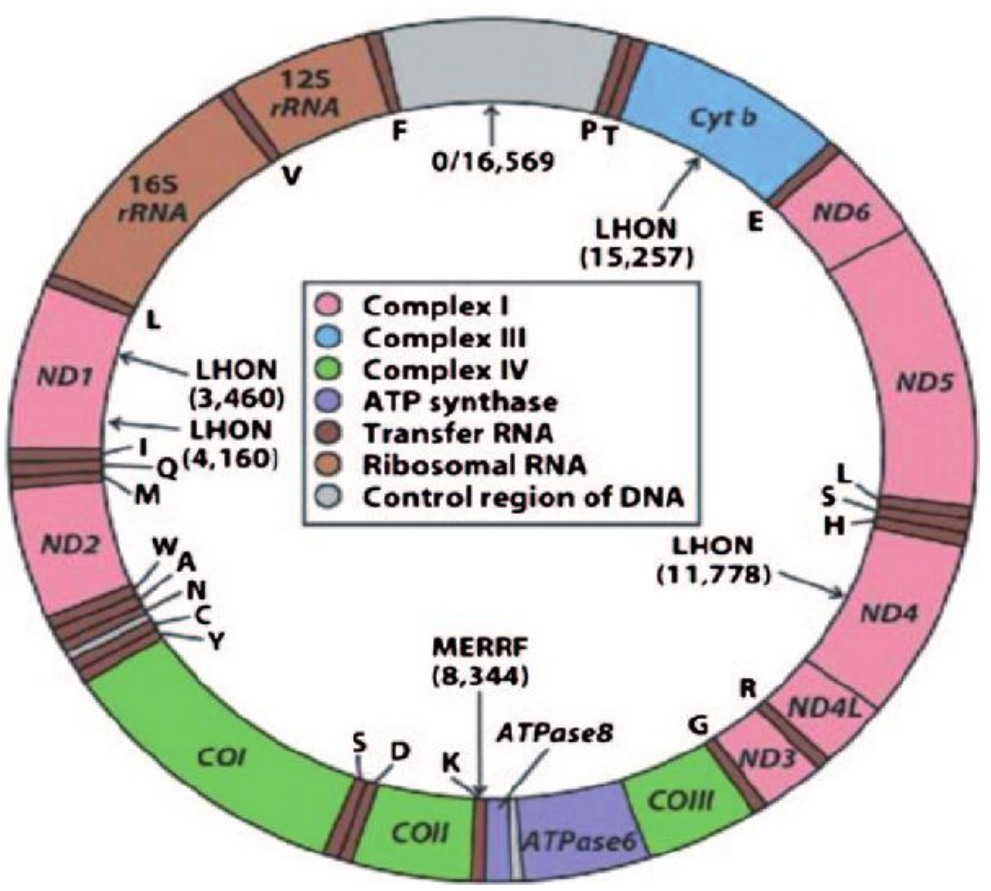

Fig. (4): Organization of insect mitochondrial genome (Source: http://chimerasthebooks.blogspot.in/2011_12_01_archive.html)

Table (4): GenBank code number and accession number of COI-mtDNA sequence

\begin{tabular}{ccccc}
\hline Specimen No. & $\begin{array}{c}\text { Sampling location } \\
\text { in Iraq }\end{array}$ & Species identity & \multicolumn{2}{c}{ Gen Bank } \\
\cline { 4 - 5 } & Bamarze/Duhok & Dacus ciliatus & Code Number & Accession Number \\
\hline 1c-1 & Gardasher/Erbil & Dacus ciliatus & Bankit 2174379 & MK 287890 \\
\hline 2c-9 & $\begin{array}{c}\text { HassanTappa/ } \\
\text { Sulaymaniyah }\end{array}$ & Dacus ciliatus & Bankit 2174377 & MK 287889 \\
\hline 3b-9 & & & MK 287888 \\
\hline
\end{tabular}




\section{REFERENCES}

Al-Jorany, R. S.; Al-Zubaidy, H. K.; Flaia, S. K. (2015). Economic Losses and Economic Threshold of Cucurbit fruit fly Dacus ciliatus (Loew) and Greater Melon fruit fly Dacus frontalis (Becker) on Cucumber Cucumis staivus L. in middle of Iraq. Journal of Kerbala for Agricultural Sciences, [S.1.], v. 2, n. 2, p. 106-117. ISSN 2616-6933.

Arghand B. 1983. Introduction in cucumber fly Dacus spp. and primary investigation of it in Hormozgan province. Appl Entomol Phytopathol, 51:3-11.

Azab, A. K. and M. T. Kira (1954). The cucurbit fly, Dacus ciliatus (Loew) in Egypt. Soc. Foad 1st d Ent, Bull., 30: 379-382.

Azab, A.K.; El-Nahal, A.K.M.; Swailem, S.M. (1971) The immature stages of the melon fruit fly, Dacus ciliatus. Bulletin de la Société Entomologique d'Egypte 54, 243-247.

Beckenbach, A.T., Joy, J.B. (2009) Evolution of the mitochondrial genomes of gall midges (Diptera: Cecidomyiidae): rearrangement and severetruncation of tRNA genes. Genome Bio. Evol. 1: 278-287.

Cheraghian A (2012). Introduction of fruits flies Ceratitis, Bactrocera, Dacus and Rhagoletis from Iran. Tunisian Journal of Plant Protection 7(2), p 117.

David, K.J., and S. Ramani. 2011. An illustrated key to fruit flies (Diptera: Tephritidae) from Peninsular India and the Andaman and Nicobar Islands. Zootaxa. 3021: 1-31.

De- meyer, M., Mohamed, S. \& White, I.M. 2012. Invasive fruit fly pests in Africa: a diagnostic tool and information reference for the four Asian species of fruit fly (Diptera, Tephritidae) that have become accidentally established as pests in Africa, including the Indian Ocean Islands. Online at: http://www. africamuseum.be/fruitfly/AfroAsia.htm (accessed 19 August 2012).

Drew, R. A. and D. L. Hancock (1994). Bactrocera dorsalis complex of fruit flies (Diptera: Daccinae) in Asia. Bull. Ent. Res., 2: 68.

Drew, R.A.I., and M.C. Romig. 2013. Tropical fruit flies of South-east Asia. CAB International, Wallingford, UK.
Drew, R.A.I., and S. Raghu. 2002. The fruit fly fauna (Diptera: Tephritidae: Dacinae) of the rainforest habitat on the Western Ghats, India. Raffles Bull. Zool. 50: 327-352.

Drew, R.A.I., M.C. Romig, and C. Dorji. 2007. Records of dacine fruit flies and new species of Dacus (Diptera: Tephritidae) in Bhutan. Raffles Bull. Zool. 55: 1-21.

Ducky, P.F., David, P. \& Quilici, S. 2004. A review of relationships between interspecific competition and invasions in fruit flies (Diptera: Tephritidae). Ecological Entomology 29: $511-520$.

Ekesi, S. 2012.Combating fruit flies in Eastern and Southern Africa (COFESA): elements of a strategy and action plan for a regional cooperation program. Online http://www.globalhort.org/media/uploads/File/ Fruit $\% 20$ Fly/Fruit $\% 20 f l y \% 20$ Issue $\% 20$ Paper\%2010.05.2010-1.pdf (accessed 19August 2012).

EPPO (2009). The European Plant Protection Organization. http:// www.eppo.org.

Fetoh, B. E. A. (2003). The pumpkin fly, Dacus ciliatus (Loew) as new and ancient pest in Egypt. The Agric. Magazine, 46: 54-55.

Folmer, o., M. Black, W. Hoeh, R. Lutz, and R. Vrijenhoek. 1994. DNA primers for amplification of mitochondrial cytochrome $\mathrm{c}$ oxidase subunit I from diverse metazoan invertebrates. Mol. Mar. Biol. Biotechnol. 3: 294-299.

Jalali S. K., Ojha R. Venkatesan T., (2015). DNA Barcoding for Identification of Agriculturally Important Insects. National Bureau of Agriculturally Important Insects, Vol. (1) 317 -330 .

Hussein M. A., N. El-Wakeil, and T. El-Sebai. 2006. Susceptibility of melon fruit fly, Dacus ciliatus, to entomopathogenic nematodes (Rhabditida) and to insecticides. Vol. 16, No. 1, pp. 13-18 International Journal of Nematology.

Leblanc, L., M.A. Hossain, S.A. Khan, M. San Jose, and D. Rubinoff. 2013. A preliminary survey of the fruit flies (Diptera: Tephritidae: Dacinae) of Bangladesh. Proc. Hawaiian Entomol. Soc. 45: 51-58. 
Lewis, D.L., Farr, C.L., Kaguni, L.S. (1995) Drosophila melanogaster mitochondrial DNA: completion of the nucleotide sequence and evolutionary comparisons. Insect Mol. Biol. 4: 263-278.

Malan, E.M.; Giliomee, J.H. (1969) Morphology and descriptions of the larvae of three species of Dacinae (Diptera: Trypetidae). Journal of the Entomological Society of South Africa 32, 259-271.

Menon, M.G.R.; Mahto, Y.; Kapoor, V.C.; Bhatia, S.K. (1968) Identities of the immature stages of three species of Indian fruit-flies Dacus cucurbitae Coquillett, D. diversus Coquillett, and D. ciliatus Loew (Diptera, Trypetidae). Bulletin of Entomology, Entomological Society of India 9, 87-94.

Nagappan K, Kamalnathan S, Santharaman T and Ayyasamy MK. 1971. Insecticidal trials for the control of the melon fruit fly, Dacus cucurbitae Coq. infesting snake gourd, Trichosanthes anguina. Madras Agric J, 58:688-690
Norrbom, A. L., L. E. Carroll, and A. Freidberg. 1998. Status of knowledge, pp. 947. In F.C. Thompson [Ed.], Fruit Fly Expert Identification System and Systematic Information Database. Myia vol. 9.

Patel, S. N. (1976). The bionomics and control measures of the Ethiopian fruit fly Dacus ciliates Loew (Tephritidae: Diptera). M.Sc. (Agri.) Thesis, Submitted to Gujarat Agricultural University, Sardarkrushinagar.

Vayssie`res J. F., Y. Carel, M. Coubes, and P. F. Duyck, 2008. Development of Immature Stages and Comparative Demography of Two Cucurbit-Attacking Fruit Flies in Reunion Island: Bactrocera cucurbitae and Dacus ciliatus (Diptera Tephritidae) Enviromental. Entomology. 37(2): 307-314

White IM and Elson-Harris MM. 1994. Fruit Flies of Economic Significance: Their Identification and Bionomics. CAB International, Oxon, UK

White, I. M. (2000). Identification of peach fruit fly, Bactrocera zonata (Saund.) in the Eastera Mediterranean, The natural History Museun, London,

UK.

$21 \mathrm{p}$. 


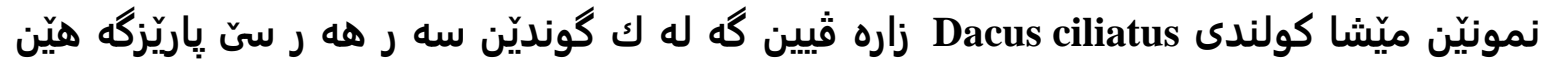

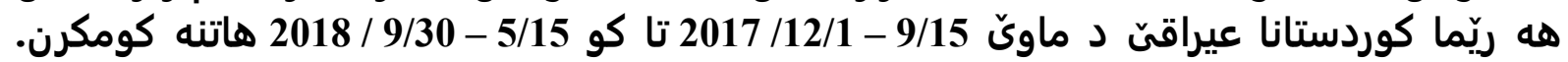

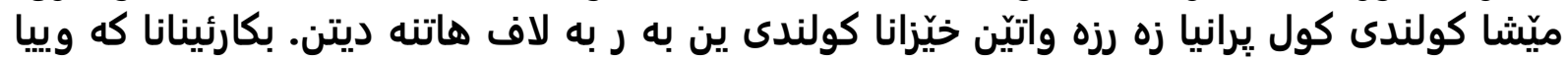

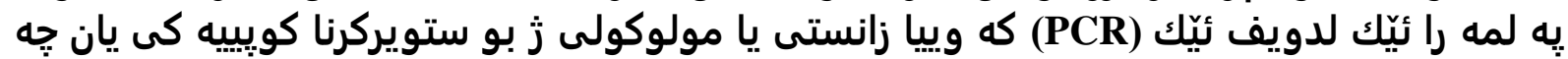

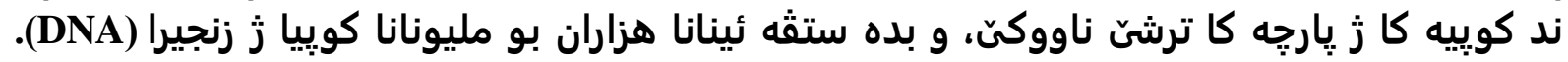

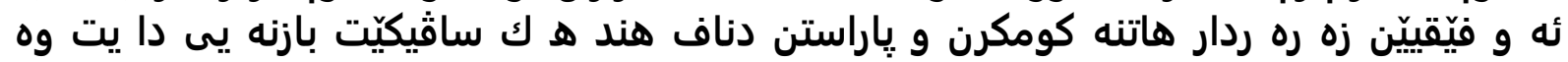

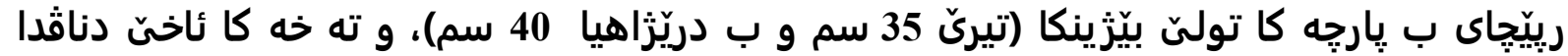

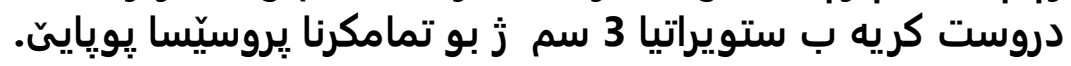

التحديد الجزيئي لذبابة القرعيات (Dacus ciliatus (Diptera: Tephritidae) التي تصيب العائلة الباذنجانية في إقليم كودستان / العراق ، استناداً إلى جين المايتوكوندريا TOI

الخلاصة

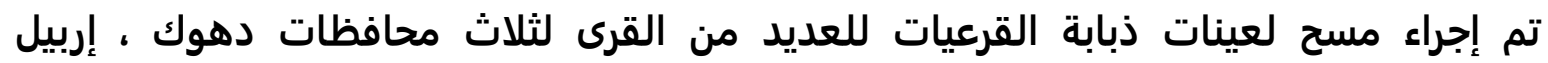

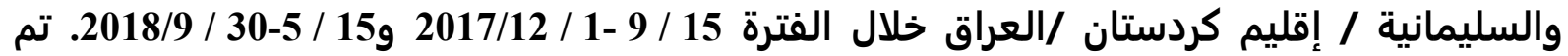

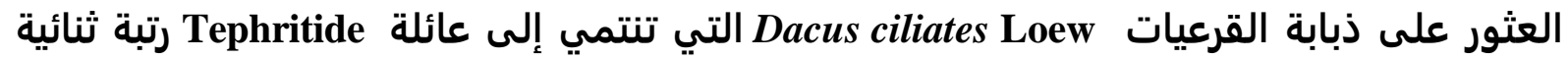

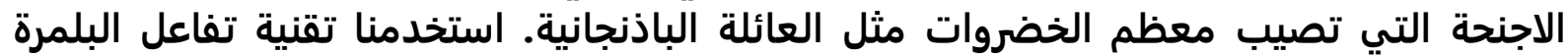

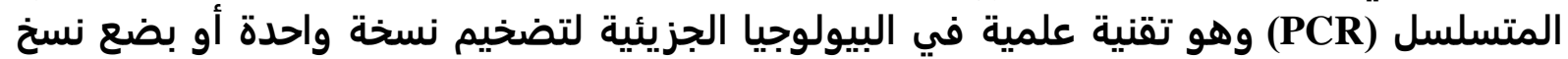

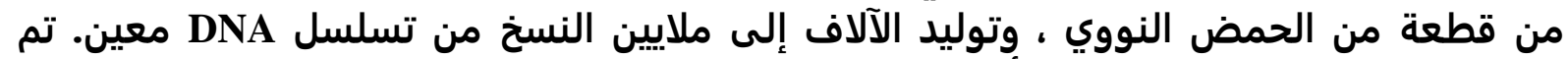

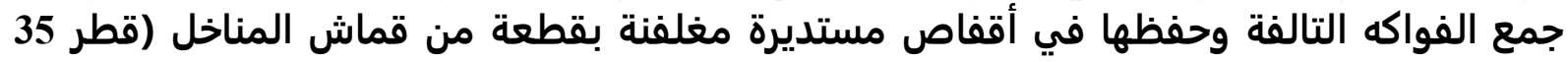
سم ، بارتفاع 40 سم) ، تحتوي على طبقة من 3 سم تربة لتسهيل عملية التعذير . 